\title{
Biyoterörizm ve Eczacılık Hizmetleri
}

\author{
Sevgi Şar, Miray Arslan, Bilge Sözen Şahne
}

\section{ÖZET}

Günümüzde biyolojik terör, çeşitli biyolojik etkenler nedeniyle insan sağlığını olumsuz yönde etkileyerek hastalık ve ölümlere neden olmaktadır. Terörist amaçlarla ortaya çıkabilen salgınlar, açılkanamayan nedenlerle de geniş kitleler üzerinde etkili olabilmektedirler. Tarih boyunca veba gibi çeşitli salgın hastalıkların pek çok savaşın sonucunu etkilediği bilinmektedir. Günümüzde ise rekabet halindeki toplulukların birbirlerine zarar vermek amacıyla biyolojik terör ajanlarını denediği gözlenmektedir.

Diğer bütün afetlerin en az olumsuz etki ile atlatılabilmesi için yapılan hazırlıklarda olduğu gibi, biyolojik terör saldırılarına karşı da önlemlerin alınması gerekmektedir. Sağlık profesyonellerinin de bu durumlara karşı vereceği hizmetler, tehlikenin azaltılmasında veya durdurulmasında büyük önem taşımaktadır.

$\mathrm{Bu}$ gibi durumlarda çeşitli biyolojik etkenlere maruz kalanların, şikâyetlerinin giderilmesi için başvuracağı ilk sağlık kuruluşlarından birinin de eczaneler olduğu bilinmektedir. Söz konusu durumlarda eczacıların, hem kendilerine başvuranları doğru yönlendirmek hem de ilgili yerlere doğru bilgi akışını sağlamak için yeterli bilgiye sahip olmaları gerekmektedir.

$\mathrm{Bu}$ çalışmada, biyolojik terör ve tehlikelerin nedenleri ve baş etme yöntemleri incelenerek verilen eczacılık hizmetleri kapsamında eczacıların üstlenebilecekleri roller açıklanmaya çalışılacaktır.

Anahtar Kelimeler: Biyoterörizm, Eczacilık Hizmetleri
Sevgi Şar, Miray Arslan

Ankara Üniversitesi Eczacılık Fakültesi, Eczacıllk İşletmeciliği Anabilim Dalı, 06100, Sihhiye - Ankara

Bilge Sözen Şahne

Hacettepe Üniversitesi Eczacılık Fakültesi, Eczacıllk İşletmeciliği Anabilim Dal, 06100, Sihhiye - Ankara

Corresponding Author:

Bilge Sözen Şahne

e-mail:bilgesozen@yahoo.com

Submitted / Gönderilme: 25.10.2016 Revised / Düzeltme: 06.12.2016 Accepted / Kabul: $\quad 07.12 .2016$

\section{GİRIŞ}

Dünya genelindeki barış söylemlerine rağmen, terör kavramı değişik şekillerde sürekli karşımıza çıkmaktadır. Özellikle Amerika Birleşik Devletleri’nde yaşanan 11 Eylül terörist saldırısı, bütün dünya ülkelerinde terörizmin oluşturacağ 1 tehlikelerin önemini ve ülkelerin terörist saldırılara karşı savunma istemlerini tekrar gözden geçirmeleri gerekliliğini ortaya çıkarmıştır $(1,2)$. Bu doğrultuda, biyolojik terör saldırıları da günümüzde sıkça konuşulan bir konu haline gelmiştir.

"Canl organizmadan elde edilen mikroorganizmalarm veya toksinlerin silah şeklinde kullanılması ile insanlarda hastalı veya ölüm oluşturması" olarak tanımlanan biyolojik terör, asırlar boyunca kullanılmış, günümüzde ise terörizmin artmasına paralel olarak yayılmıştır $(1,3)$. Düşük maliyet ve basit bir teknik destek yardımıyla güçlü bir biyolojik silaha dönüşebilen bu hastalık yapıcı veya öldürücü ajanlar, terörist gruplar tarafından da bir tehdit unsuru olarak

Bu çalışma, 23-26 Eylül 2014'te, Van'da düzenlenen, 6. Tip Etiği ve Hukuku Sempozyumu'nda sunulan "Biyoloji Terör ve Tehlikelerde Eczacılık Hizmetleri" başlıklı bildirinin genişletilmiş halidir. 
kullanılmaya başlanılmıştır $(2,3)$. Çok küçük miktardaki bir ajan, kişiden kişiye bulaşma nedeniyle oldukça geniş kitleleri etkileyebilmektedir (4). Dünya Sağlık Örgütü (DSÖ)'nün Amerika'da biyolojik terörün açabileceği zararları ortaya çıkarmak üzere yaptığı bir çalışmada, $50 \mathrm{~kg}$ Bacillus anthracis sporunun, uygun hava akımı ile dağılması sonucu büyük yerleşim alanlarında yaşayanların en az yarısını öldürebileceği veya etkisiz hale getirebileceği saptanmıştır (1, 5). Bu gibi saldırılar ülkelerin sağlık sistemlerini de olumsuz yönde etkileyeceğinden, sağlık sektörünün vazgeçilmez bir parçası olan eczacılara da bu konuda önemli görevler düşmektedir.

\section{BİYOLOJÍK TERÖR}

Biyolojik silahların kullanımının insanlık tarihi kadar eski olduğu söylenmekle birlikte, biyolojik silahlarla bilinen ilk kitle imhası, 14. yüzyılda Kaffa Kuşatması sırasında vebadan ölenlerin cesetlerinin mancınıklarla şehir surları üzerinden kale içine atılmasıyla tüm şehir halkının birkaç ayda ölmesine neden olan Tatarlar tarafından gerçekleştirilmiştir (2). Bunun yanı sıra, I. ve II. Dünya Savaşları’nda da biyolojik silahların kullanıldığı bilinmektedir. Bugüne kadar önemli savaş silahı olarak kullanılmamış olmakla beraber, bütün dünya ülkelerince biyolojik silahlar geleceğin silahı olarak kabul edilmekte ve bu silahlarla ilgili çalışmalar sürdürülmektedir (6).

Biyolojik silahlardaki hızlı ilerleme ve gelişmelerin üzerine, 1975 yılında, 144 ülkenin katılımı ile imzalanan, "Bakteriyolojik ve toksin silahlarının geliştirilmesi, üretimi, depolanması ve imhasına dair anlaşma" yürürlüğe girmiştir. Ancak bu anlaşmaya rağmen, biyolojik silah üretiminin artarak günümüze kadar sürdüğü ve özellikle Çin, Mısır, Hindistan, İran, Kuzey Kore, Libya, İsrail ve Suriye gibi bazı ülkelerin biyolojik silah programı olduğu ile ilgili bilgiler olduğu belirtilmektedir (5-8).

Biyoterör, toplumda normal yaşamı durdurmak veya ideolojik bir avantaj kazanmak amacı ile biyolojik etkenlerin şahıslara, gruplara veya daha geniş nüfusa karşı korku yaratmak hastalk oluşturmak veya hastalk oluşturma korkusu yaratmak amacıyla kullanılması olarak tanımlanmaktadır (8). Biyoterör amaçlı kullanılan silahlar; biyolojik ajanlar, posta sırasında taşındığı kutu, taşıma sistemleri (roketler, hava yolu, tren yolu) ve yayılma olmak üzere dört önemli bileşenden oluşmaktadır (3). Biyoterörizm ajanlarının ucuz oluşları, çok ve kolay üretilebilmelerinin dışındaki bazı özellikleri şu şekilde sıralanabilmektedir (9):
Öldürücülüğü ve enfektivitesi yüksektir,

Enfeksiyon dozu küçük miktarlarda ortaya çıkabilir,

Çevre koşullarına dirençlidir,

Etkin dağılıma sahiptir, hava, su ve yiyeceklerle yayılabilir,

Depolanabilir, istenildiğinde dağıtıma hazır olabilir,

Etkili bir tedavisi yoktur,

İnsandan insana bulaşması mümkündür.

Terörist amaçlı biyolojik ajanlar genel olarak patojen veya toksinin enjekte edilmesi; bir patojen veya toksinin yiyecek, içecek, gıda katkı maddeleri veya ilaçlara katılması ve patojen veya toksin süspansiyonlarının hedef bölgelere aerosolle püskürtülmesi gibi, üç farklı yolla uygulanmaktadır $(8,9)$.

Bir terör saldırısından sonra; bitki ve hayvanlarda alışılmışın dışında belirtiler (anormal renk değişiklikleri olması, hayvanlarda ani ve aşırı sayıda ölüm görülmesi, çevrede normalde o bölgede görülmeyen mantarların ve böceklerin ortaya çıkması), insanlarda hızla artan ateş, öksürük ve ishal durumlarının görülmesi; yaşa, coğrafyaya, mevsimlere uygun olmayan bir hastalığın ortay çıması ve kamuoyuna açıklama yapılması gibi durumlar gözlendiği takdirde, biyolojik bir savaş ajanının kullanıldığı ihtimali üzerinde durulabilmektedir (3).

Hastalık Kontrol Merkezi (Centers for Disease Control and Prevention, CDC), potansiyel olarak biyoterör veya biyolojik silah ajanı olarak kullanılabilecek biyolojik ajanları üç kategoride (Kategori A, B, C) gruplandırmıştır (10-12). Bu sinıflandırmaya göre, Kategori A ulusal güvenlik için yüksek derecede risk taşıyan ajanları (Variola Major - Çiçek, Basillus anthracis-Şarbon, Yersinia pestis (plague)-Veba, Clostridium botulinum toksini-Botulizm, Francisella tularensisTularemi, Filoviruslar (Ebola, Marburg)-Viral kanamalı ateş, Arenavirüsler gibi), Kategori B ikinci dereceden riskli ajanları (Coxiella burnetii-Q ateşi, Brucella species-Bruselloz, Burkholderia pseudomallei/mallei-Ruam/Melioidoz, Alfavirusler (Venezuella, doğu ve batı at ensefalomiyeliti)Ensefalit, Toksinler (Risin, Clostridium perfringens, SEB)Toksik sendromlar gibi) ve Kategori $\mathrm{C}$ ise gelecekte kitlelere yayılması için tasarlanmış gelişim gösteren patojenlerden oluşan üçüncü dereceden riskli ajanları (Nipah virüsü, Hantavirüs-Viral hemorajik ateş, Kene kaynaklı kanamalı ateş virüsleri, Kene kaynaklı ensefalit virüsleri, FlavivürüsSarı ateş, Mycobacterium tuberculosis- Çoklu ilaca dayanıklı tüberküloz gibi) içermektedir (10). 


\section{BIYOLOJIK TERÖR ve TEHLİKELERDE ECZACININ ROLÜ}

Biyoterör eylemlerinde, sağlık otoriteleri, istihbarat, güvenlik, yargı otoritelerinin koordineli olarak çalışmasının gerekliliği bilinmektedir (8). Böyle bir olayla karşılaşılmadan önce sağllk personeline biyolojik ajanlarla oluşacak hastalıkların kliniği, tanısı, profilaksisi, tedavisi, örneklerinin taşınması, bariyer önlemleri ve sağlıklı bireylerin korunması konularını içeren bir eğitim verilmelidir. Sağlık sisteminin önemli bileşenlerinden biri olan eczacılara da diğer acil durumlarda olduğu gibi, biyolojik terörle karşı karşıya kalınması durumunda önemli görevler düşmektedir (13-18). Biyolojik terör saldırısına maruz kalan bireylerin ilk başvuru noktası olacak olan yer hastanelerdir. Ancak, hastanelerin ve hastane eczanelerinin bu eylemlerde kullanılma olasilığ olduğu da bilinmektedir. Bu nedenle, özellikle hastane eczacılarının biyolojik terör konusunda bilinçli olmaları gerekmektedir. Örneğin, bir şarbon maruziyet tedavisi için hastane eczanesinde karşılaşılan bir durum, potansiyel bir biyoterörizm tehdidi olarak düşünülmeli ve eczacılar doktorla iletişime geçerek tedavinin doğruluğunu teyit etmelidir (18). Ayrıca, biyolojik terör saldırısı sonucunda ortaya çıkan salgınla birlikte acil servise ulaşamayan hastaların ilk başvuracağ 1 adres eczaneler olacağından, serbest eczacıların da böyle bir duruma karşı hazırlıklı ve gerekli bilgilere sahip olmaları büyük önem taşımaktadır.

Eczacıların bu tarz saldırılar sonrasında aktif rol alabilmeleri açısından, özellikle terörist grupların önceden kullandıkları şarbon, Pneumonic Plaque, ebola, çiçek hastalığ1 virüsü, influenza ve Botulinum toksini ve Stafilokok enterotoksini gibi biyolojik silahlar hakkında bilgi sahibi olmaları faydalı olacaktır (1). Bu sayede eczacılar tedavi için gerekli olabilecek ilaç ve tıbbi malzemeleri daha hızlı temin edecek, aynı zamanda diğer sağlık personelleriyle koordineli bir şekilde yapılacak çalışma ile ortaya çıkan korku ve panik ortamında işlemler kolaylaşacaktır. Biyolojik saldırıya maruz kalan bireylere öncelikle uygulanması gereken aşılama ve proflaktik antibiyotik tedavisinde eczacıların katkısı oldukça büyük olacaktır (8). Örneğin; Antrax virüsü, Pneumonic Plaque, Botulinum toksini gibi biyolojik maddeler için aşı ile ilgili gerekli bilgilendirme ve tedbirlerin alınması; Ebola virüsü, Stafilokok enterotoksini gibi biyolojik ajanlar için de nasıl bir destekleyici tedavi uygulanması gerektiği konusunda, eczacıların diğer sağlık çalışanları ile işbirliği içerisinde olması gerekmektedir (1). Setlak’a göre, biyoterör vakasında yer alacak eczacıların sağlık sisteminde, 4 farklı alanda görevi bulunmaktadır (19): a. Yanıt Entegrasyonu: Bu aşamada eczacılar ilaçların uygun dağıtımını sağlamalı, biyoterörle ilgili konularda kendi alanları ile ilgili konularda bilgilendirme yapmalı, ilk yardım ve yaşam desteği gibi konulardaki becerilerini geliştirmeli, hasta danışmanlığı konusunda diğer sağlık personeline yardımcı olmalıdır.

b. Hasta Yönetimi: İlaç tedavisi yönetiminde acil durumlarda da önemli görev alan eczacılar biyoterör olaylarında da bu görevin yanı sıra panik ve korkuyu önlemede yardımcı olmaktadirlar.

c. Farmasötik Tedariki: Eczacılar, biyoterör olaylarında stoklara uygun tedaviyi seçerek, etkili bir dağıtım ve kontrol sistemi sağlamalıdırlar. Ayrıca, uygun ambalaj, stoklama, taşıma ve etiketleme sağlamalı ve özel, doğru ve tam hasta kaydı toplamaya devam etmelidirler.

d. Politika Koordinasyonu: Biyoterör olaylarında eczacılar, diğer sağlık personeli ile birlikte hasta tanı ve tedavisi için rehber hazırlama, israfı önlemek için gerekli işbirliklerini sürdürme gibi aşamalarda da görev almaktadır.

Biyolojik terör saldırısına maruz kalınması halinde ortaya çıkabilecek bazı durumlar ve eczacıların yapması gerekenleri şu şekilde sıralamak mümkündür (1):

Eczacılar, biyolojik materyallere maruz kalma sonucu oluşan belirtilere sahip kişi sayısının artması halinde ilgili merkezle görüşerek olayın ciddiyetinin anlaşılmasına yardımcı olabilirler.

Bölgeye sevk edilen tedavi amaçlı ilaçların uygun şekilde muhafaza ve sevk işlemlerinde eczacının rolü tartışılmazdır.

Sağlık ekibinin bir üyesi olarak eczacı o bölgede daha ileri bir bulaşmaya karşı bireyleri uyarmada ve gerekli korunma tedbirlerini kişilere aktarmada önemli bir yere sahiptir.

> Hastaların doğru ve tam olarak tedavi olmaları için, verilen ilaçların kullanımı hakkında bilgilendirme yapmak eczacının görevidir.

Olası yan etkilere karşı hastalar bilgilendirilmeli ve hastaların tedavilerini bu nedenle yarıda bırakmaları önlenmelidir.

> Güncel halk sağlığı bilgileri ile hasta donatılarak olası paniklerin önüne geçilmelidir.

> Hekim, hemşire ve diğer sağlık personeline, spesifik ilaç tedavisi hakkında bilgi vermek de eczacının sorumluluğu altındadir. 
Genel olarak bakıldığında, biyoterör eylemlerinin ardından, ilaçların dağıtımı, hastaların bilgilendirilmesi ve diğer sağlık personelinin koordinasyonunun sağlanmasında eczacılara büyük görev düşmektedir (18). Eczacıların bu görevi iyi bir şekilde yürütebilmesi için, biyoterör ile ilgili bilgilerini güncel tutmaları gerekmektedir. Bu amaçla, eczacılara yönelik, biyoterör ile ilgili dünya genelinde birçok web sayfası hizmet vermektedir (19).

\section{SONUÇ ve TARTIŞMA}

Sürekli gelişim ve değişim, dünyada bazen olumsuz sonuçlara da neden olabilmektedir. Savaş, terör gibi kavramlar geçmişe göre günümüzde daha farklı şekillerde karşımıza çıkmaktadır. Bunlar arasında en dikkat çekeni ise biyoterörizmdir. Son yıllarda terörist saldırıların yoğunlaştığ 1 bir dünyada, ülkemizin coğrafik ve jeopolitik konumu düşünüldüğünde biyoterörizm riski ne yazık ki yadsınamaz bir gerçektir (9). Ülkemizde bugüne kadar bilinen büyük bir biyoterör vakası olmayışından dolayı böyle bir durumla karşılaşıldığında hazırlıksız olmamak için, sağlığı yakından ilgilendiren bu konu hakkında gerekli tüm sağlık personeli bilinçlendirilmelidir.
Sağlığın söz konusu olduğu hemen hemen her konuda önemli yer tutan eczacılar, biyolojik terör ve tehlikelerde de görev almaktadırlar. Eczacıların bu alanda daha etkili bir hizmet sunabilmeleri için kendilerini geliştirmeleri oldukça önem taşımaktadır. Bu bağlamda, eczacıların kendi bölgelerindeki sağlık kuruluşlarından haberdar olmaları, biyolojik terör amaçlı kullanılan ajanlar, bu ajanlara maruz kalan kişilerin tedavileri ve tedavilerinde kullanılan ilaçlar gibi konularda bilgi sahibi olmaları, biyolojik terör gibi durumlardan sonra gönüllü olmaları ve neler yapabilecekleri hakkında kendilerini ve meslektaşlarını bilgilendirmeleri, bu konuya yönelik eğitimler almaları oldukça fayda sağlayacaktır.

Eczaciların biyolojik terör ve tehlike durumlarında daha aktif rol oynamalarını sağlamak amacıyla gerek lisans ve gerekse lisanüstü eğitimlerinde bu konulara yer verilmeli ya da ilgi duyan öğrenciler başka birimlerde verilen konu ile ilgili dersleri alması için yönlendirilmelidir. Ayrıca, meslek örgütleri biyoterör ile ilgili meslek içi eğitimler düzenleyerek eczacıların bu konuda kendilerini geliștirmesini sağlamalıdır. Böylece halkla iç içe yaşayan eczacılar halkın biyoterör hakkında bilinçlenmesine yardımcı olacaktır. Bunların yanı sıra, biyoterör ile ilgili ulusal sağlık politikalarında eczacıların da yer alması sağlanmalıdır.

\section{Bioterrorism and Pharmacy Services}

\section{ABSTRACT}

Nowadays, biological terror cause illness and death by effecting people health in a negative way because of various reasons. The epidemics that occur as terrorist purposes can influence over the masses with unexplained reasons. Throughout history, epidemic diseases as plague effected the results of lots of wars is known.

Today, communities in competing try biological terror agents to damage each other is observed. Precautions should be taken to biological terror attacks like as all other diseases for getting over them with minimum negative effects. So, services giving by health care professionals at these situations are very important to reduce or stop the danger.

It is known that pharmacies are the one of the health authorities that people who exposure various biological agents at these situations firstly go. The pharmacists should have enough information to correctly route people who came pharmacies and to provide right information flow to related places at mentioned situations.

In this study, the scope of given pharmacy services, pharmacists' roles will be tried to explain by examining reasons of biological terror and danger and coping strategies with them.

Key Words: Bioterrorism, Pharmacy services 


\section{KAYNAKLAR}

1. Banoğlu E. Biyolojik Terör (Eczacıya Yeni Görev). Eczacı Dergisi 2003;3: 9-11.

2. Gökçe G. Biyolojik Terör ve Biyolojik Savaş. Sağlık’ta Nabız Dergisi 2001;8: 16-39.

3. T.C. Sağlık Bakanlığı Türkiye Kamu Hastaneleri Kurumu, Trabzon İli Kamu Hastaneleri Genel Sekreterliği Kanuni Eğitim ve Araştırma Hastanesi. Hastane Afet ve Acil Durum Müdahale Planı 2013. Available from: http://www. trabzonnumune.gov.tr/detay.php?id=453\&cid=271 [Accesed 02.09.2014].

4. Lillibridge S. A public health response to bioterrorism. Med Glob Surviv 2000;6: 82-5.

5. Doğanay M. Biyoterör ve şarbon. ANKEM Dergisi 2002;16: 254-8.

6. Bursa Sağlık Müdürlüğü, Biyolojik Savaş ve Korunma. Available from: http://bhsm.gov.tr/sivil_savunma/ [Accesed 02.09.2014].

7. Alp E, Doğanay M. Biyoterörizm. Yoğun Bakım Dergisi 2006;6: 135-46.

8. Yemen OŞ, Doğanay M. Biyoterörizm. ANKEM Dergisi 2008;22: 95-116.

9. Aksoy Ü. Biyoterörizm, potansiyel biyoterörizm ajanı olan parazitler ve biyogüvenlik çalışmaları. Mikrobiyoloji Bülteni 2006; 40: 129-39.
10. CDC, Emergency Preparedness and Response. Available from: https://emergency.cdc.gov/bioterrorism/index.asp [Accessed: 02.09.2014].

11. Pınar A. Biyolojik silah olarak mikroorganizmalar. Hacettepe Tip Dergisi 2010;41: 97-104.

12. Serinken M, Kutlu SS. Biyoterörizm ve şarbon. Türkiye Acil Tip Dergisi 2009;9: 185-90.

13. Hilton T, Montgomery S, Herring P, Gamboa-Maldonado T, Sinclair R, McLaughlin B. Perceived attitudes and staff roles of disaster management at CBOCs. Fed Prac 2015;32: 12-20.

14. Lee JJ, Johnson SJ, Sohmer MJ. Guide for mass prophylaxis of hospital employees in preparation for a bioterrorist attack. Am J Health-Syst Pharm 2009;66: 570-5.

15. Anderson PD, Bioterrorism: Toxins as weapons. J Pharm Pract 2012;25: 121-9.

16. Agomo CO. The role of community pharmacists in public health: A scoping review of the literature. J Pharm Health Serv Res 2012; 3: 25-33.

17. Ford H, Trent S, Wickizer S. An Assessment of state board of pharmacy legal documents for public health emergency preparedness. Am J Pharm Educ 2016;80: Article 20.

18. Lomaestro BM. The role of the pharmacist. Medscape 2001. Available from: http://www.medscape.com/ viewarticle/408587 [Accessed: 01.07.2016].

19. Setlak P. Bioterrorism preparedness and response: Emerging role for health-system pharmacists. Am J Health-Syst Pharm 2004;61: 1167-75. 